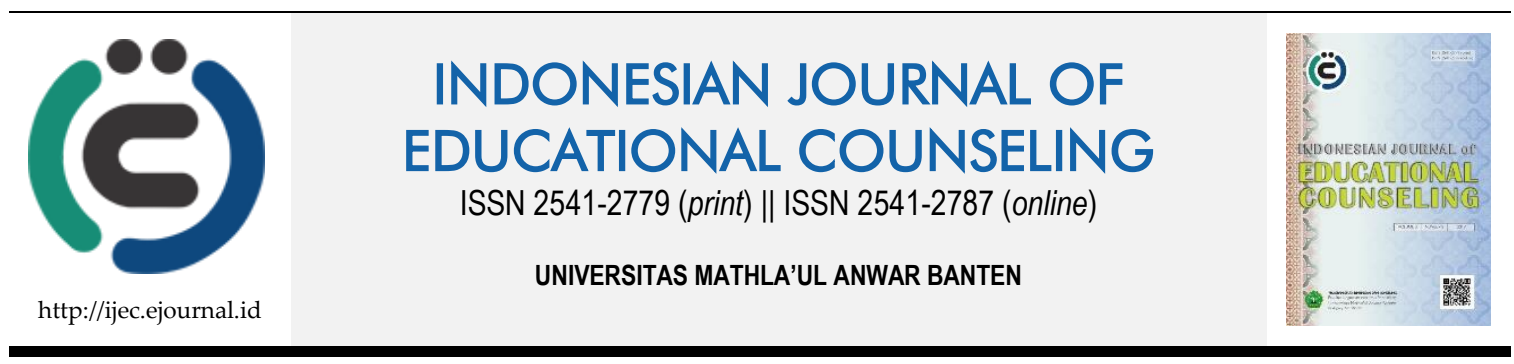

Research Based Article

\title{
Profil Kompetensi Pedagogik dan Profesional Guru Bimbingan dan Konseling di Kota Bandung
}

\author{
Nurnaifah Selvia Wardhani ${ }^{1}$, Euis Farida ${ }^{2}$, Eka Sakti Yudha ${ }^{3}$ \\ 1, 2, 3 Universitas Pendidikan Indonesia
}

\begin{tabular}{ll}
\hline Article History & ABSTRACT \\
\hline Received: 26.12.2018 & PROFIL OF PEDAGOGIC AND PROFESSIONAL COMPETENCIES OF \\
Received in revised form: & SENIOR HIGH SCHOOL COUNSELORS IN BANDUNG CITY. This study \\
25.04.2019 & aims to get a profile and description of pedagogic and professional \\
Accepted: 02.07.2019 & competencies of guidance and counseling teachers (counselor) in Bandung. The \\
Available online: 23.07.2019 & research used the quantitative approach with survey methods. The population \\
& of this research is 127 counselors of the senior high school in Bandung. The \\
& Instrument was the development of Permendiknas No. 27 Tahun 2008 \\
& concerning Academic Qualification Standards and Counselor Competencies \\
& with ten aspects related to pedagogic and professional competencies. Data \\
& analysis techniques in this research are descriptive analysis techniques. The \\
& result of the research shows that the profile of counselors is in the competent \\
& category but in several aspects need some developed. The result of the research \\
& can be used as a need assessment for supervisor in understanding counselors \\
& competencies so that it can be used as a basis to provide guidance and \\
& counseling services effectively and efficiently. \\
& KEYWORDS: Guidance and Counseling Teachers, Pedagogic Competence, \\
& Professional Competence. \\
\hline
\end{tabular}

DOI: $10.30653 / 001.201932 .63$

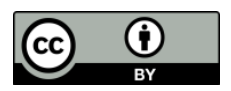

This is an open access article distributed under the terms of the Creative Commons Attribution 4.0 International License, which permits unrestricted use, distribution, and reproduction in any medium, provided the original work is properly cited. ๑) 2019 Nurnaifah Selvia Wardhani, Euis Farida, Eka Sakti Yudha.

\section{PENDAHULUAN}

Peran guru bimbingan dan konseling (BK) di dunia pendidikan semakin kompleks dan berat karena esensi dari fungsi guru BK adalah membantu konseli merubah perilaku dan persepsi dirinya untuk memenuhi keseimbangan aspek pribadi, sosial, pendidikan, dan karirnya. Untuk dapat membantu konseli mengembangkan potensi secara optimal dibutuhkan guru BK yang memahami akan kualitas dan kompetensi yang dimilikinya serta dapat menjalankan teori dan praksis pendidikan terutama esensi layanan bimbingan dan konseling. Namun, tantangan dan permasalahan pendidikan dewasa ini semakin kompleks dan berat menuntut peran konselor bekerja lebih profesional. Konselor yang profesional akan memenuhi kompetensi dirinya untuk dapat bekerja secara maksimal.

${ }^{1}$ Corresponding author's address: Departemen Psikologi Pendidikan dan Bimbingan FIP Universitas Pendidikan Indonesia. Jl. Dr. Setiabudi No. 229, Isola, Kec. Sukasari, Kota Bandung, Jawa Barat 40154; Email: selviaward@gmail.com 
Hanya saja, "mengingat konselor diasumsikan sebagai pribadi yang akan membimbing konseli dalam mencapai tujuan tertentu, maka dalam relasi ini sangat dibutuhkan adanya kapasitas tertentu yang harus dimiliki oleh seorang konselor" (Fuad, 2009, hlm. 247). Kapasitas tersebut ditentukan oleh pengalaman dan profesionalitasnya dalam bekerja sebagai konselor yang kompeten (Mudjijanti, 2014, p. 260).

Seseorang dinyatakan kompeten di bidang tertentu bila ia menguasai kecakapan kerja atau keahlian yang selaras dengan tuntutan bidang kerja yang bersangkutan. Lyle dan Spencer (1993, p. 9, dalam Rofiqah, 2013, pp. 2-3) mengemukakan "competencies are underlying characteristics of poeple and indicate "ways of behaving or thinking, generalizing across situations, and 3 enduring for a reasonably long period of time". Pendapat ini dapat diartikan bahwa kompetensi merupakan karakteristik yang terdapat dalam diri seseorang dan menunjukkan cara ia bersikap, berpikir dan merespon terhadap situasi yang tinggal dalam diri seseorang dalam jangka waktu tertentu. Dalam Undang-Undang Republik Indonesia No. 14 Tahun 2005 Tentang Guru dan Dosen dijelaskan bahwa "kompetensi adalah seperangkat pengetahuan, keterampilan, dan perilaku yang harus dimiliki, dihayati, dan dikuasai oleh guru atau dosen dalam melaksanakan tugas keprofesionalan". Selain itu, kompetensi disebut juga sebagai kontinum perkembangan mulai dari proses kesadaran, akomodasi, dan tindakan nyata sebagai wujud kinerja (Suherman, 2015, p. 118).

Adapun karakteristik dari kompetensi guru bimbingan dan konseling telah dikembangkan dan dirumuskan atas dasar kerangka pikir yang menegaskan konteks tugas dan ekspektasi kinerja konselor yang dirumuskan ke dalam kompetensi pedagogik, kepribadian, sosial, dan profesional. Diantara keempat kompetensi tersebut, kompetensi profesional dan pedagogik yang lebih difokuskan oleh peneliti di dalam penelitian ini. Kompetensi pedagogik berkaitan dengan pengelolaan proses pelayanan bimbingan dan konseling yang diberikan kepada siswa; kompetensi kepribadian berkaitan dengan etika akademik seorang konselor atau guru BK dalam pelaksanaan bimbingan dan konseling; kompetensi sosial berkaitan dengan komunikasi dalam melakukan pelayanan bimbingan dan konseling; dan kompetensi profesional berkaitan dalam menguasai bidang keilmuan bimbingan dan konseling (Anisah, 2016, p. 59).

Ekspektasi kinerja konselor dalam menyelenggarakan layanan profesional perlu memenuhi sikap kepercayaan diri, empati, menghargai, menghormati dan mengutamakan kepentingan konseli, dengan selalu mencermati dampak jangka panjang dari hasil layanan yang diberikan. "Pengakuan secara eksplisit dan kesejajaran posisi antara kualifikasi tenaga pendidikan satu dengan yang lainnya mengandung arti bahwa setiap tenaga pendidik, termasuk konselor, memiliki keunikan konteks dalam tugas, ekspektasi kinerja, dan setting layanan" (Kamaluddin, 2011, p. 451).

Namun pada fakta lapangan, berkenaan dengan kompetensi menyelenggarakan, merancang, melaksanakan, mengevaluasi program bimbingan dan konseling, masih ditemui guru bimbingan dan konseling yang belum memiliki kemampuan optimal dalam menyelenggarakan layanan bimbingan dan konseling terutama dalam merancang dan menyusun program bimbingan dan konseling, sehingga masih terlihat dalam pelaksanaan program, bahwa guru bimbingan dan konseling bingung dan tidak mengerti dalam melaksanakan program bimbingan dan konseling (Nurrahmi, 2015, p. 47). Dari hasil supervisi akademik pengawas sekolah diperoleh informasi bahwa meskipun di dokumen RPL tertulis metode pembelajaran modeling, role playing atau yang lain, tetapi dalam praktik di kelas tetap menggunakan ceramah (Retnowati, 2016, p. 3). 
Kompetensi pedagogik dan profesional dari guru BK yang kurang optimal dapat menimbulkan adanya kesenjangan antara harapan siswa dan kenyataan dalam layanan Guru BK di lapangan. Pelaksanaan layanan bimbingan dan konseling yang diharapkan pun tidak akan berjalan dengan optimal. Tugas dan kewajiban guru BK akan terbengkalai, sehingga guru BK kehilangan eksistensi konteks kinerja di sekolah bimbingan dan konseling. Pelayanan yang dilakukan konselor tidak berada dalam konteks tugas kawasan yang memandirikan individu dalam pengambilan keputusan guna mencapai perkembangan secara optimal, mewujudkan kehidupan yang produktif dan sejahtera, serta untuk menjadi warga masyarakat yang peduli pada kemaslahatan umum melalui pendidikan (Anisah, 2016, p. 60).

Kenyataan hasil survei lapangan di atas dapat merupakan pencerminan dari peningkatan kompetensi yang masih belum mencerminkan adanya proses ideal yang seharusnya dilakukan oleh supervisor kepada guru bimbingan dan konseling. Maka dari itu, penelitian ini dilakukan dengan harapan membantu meningkatkan kompetensi guru bimbingan dan konseling lebih terarah dan pelaksanaan layanan bimbingan dan konseling dapat berjalan optimal.

\section{METODE}

Penelitian ini termasuk jenis penelitian kuantitatif deskriptif dengan metode survei. Untuk pengumpulan sampel pada Guru Bimbingan dan Konseling di SMA Negeri seKota Bandung digunakan cluster random sampling dengan jumlah populasi sebanyak 127 orang guru bimbingan dan konseling. Metode pengumpulan data yang digunakan dalam penelitian ini adalah angket (kuesioner). Instrumen yang digunakan merupakan pengembangan dari Permendiknas no. 27 tahun 2008 tentang Standar Kualifikasi Akademik dan Kompetensi Konselor dengan 10 aspek kompetensi terkait kompetensi pedagogik dan profesional. Teknik analisis data yang digunakan dalam penelitian ini adalah teknik analisis deskriptif persentase.

\section{HASIL DAN PEMBAHASAN}

Gambaran umum kompetensi pedagogik dan profesional guru bimbingan dan konseling di SMA Negeri se-Kota Bandung yang terdiri dari 10 aspek kompetensi pedagogik dan profesional dengan jumlah 127 guru BK digambarkan melalui rata-rata yang diperoleh bedasarkan pengkategorian sangat kompeten, kompeten, diambang, dan berkembang. Distribusi frekuensi kompetensi guru bimbingan dan konseling di SMA Negeri di Kota Bandung secara rinci dapat dilihat pada Tabel 1.

Tabel 1. Distribusi Kategorisasi dan Frekuensi Gambaran Kompetensi Guru Bimbingan dan Konseling di SMA Negeri se-Kota Bandung

\begin{tabular}{lllll}
\hline No & Interval Skor & Frekuensi & $\%$ & Kategori \\
\hline 1. & $76-100$ & 3 & 2 & Sangat Kompeten \\
\hline 2. & $51-75$ & 55 & 43,5 & Kompeten \\
\hline 3. & $26-50$ & 42 & 33 & Diambang \\
\hline 4. & $0-25$ & 27 & 21,5 & Berkembang \\
\hline Total & 127 & 100 & - \\
\hline
\end{tabular}


Hasil analisis data penelitian secara keseluruhan tentang kompetensi pedagogik dan professional guru bimbingan dan konseling di SMA Negeri Se-Kota Bandung menunjukkan bahwa $2 \%$ guru BK memiliki tingkat kompetensi berada pada kategori sangat kompeten, 43,5\% guru BK lainnya memiliki tingkat kompetensi pada kategori kompeten, 33\% guru BK lainnya memiliki tingkat kompetensi pada kategori diambang, dan sisanya 21,5\% guru BK berada pada kategori berkembang.

Gambar 1. Diagram Frekuensi Gambaran Kompetensi Guru Bimbingan dan Konseling di SMA Negeri se-Kota Bandung

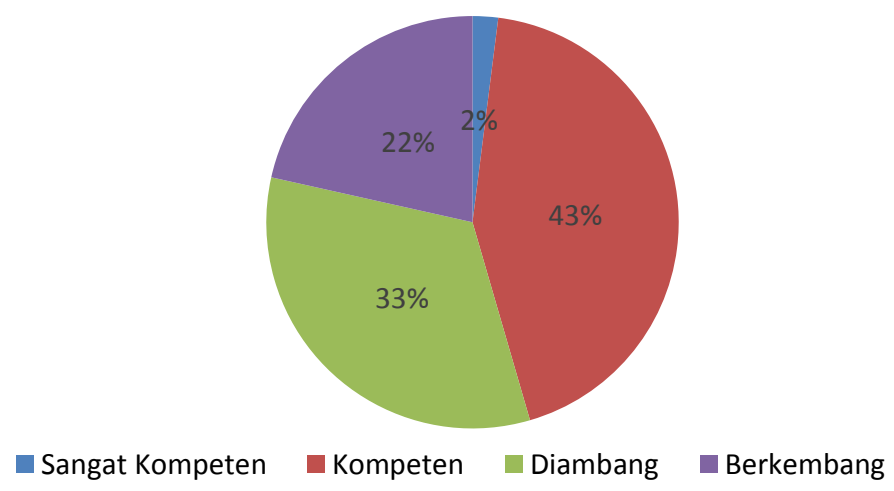

Dengan demikian sebagian besar guru BK di SMA Negeri Se-Kota Bandung sudah berada pada kategori kompeten yang berarti sudah menguasai dengan baik kompetensi pedagogik dan profesional serta mampu mengimpelementasikan dalam pelaksanaan pelayanan bimbingan dan konseling di sekolah sesuai dengan Permendiknas no. 27 tahun 2008.

Tabel 2. Distribusi Frekuensi Gambaran Kompetensi Pedagogik Guru Bimbingan dan Konseling di SMA Negeri se-Kota Bandung

\begin{tabular}{llllll}
\hline $\begin{array}{l}\text { Kompetensi } \\
\text { Pedagogik }\end{array}$ & $\begin{array}{l}\text { Sangat } \\
\text { Kompeten }\end{array}$ & Kompeten & Diambang & Berkembang & Total \\
\hline Jumlah & 2 & 67 & 32 & 27 & 127 \\
\hline Persentase & $1 \%$ & $53 \%$ & $25 \%$ & $21 \%$ & $100 \%$ \\
\hline
\end{tabular}

Pemaparan hasil analisis deskriptif persentase data penelitian pada kompetensi pedagogik guru bimbingan dan konseling di SMA Negeri Se-Kota Bandung menunjukkan bahwa $1 \%$ gutu BK yang berada pada kategori sangat kompeten, $53 \%$ guru BK berada pada kategori kompeten, $25 \%$ guru BK berada pada kategori diambang, dan sisanya $21 \%$ guru BK berada pada kriteria berkembang. Rata-rata sudah menunjukkan hasil yang tinggi, namun pada beberapa indikator masih menunjukkan tingkat penguasaan kompetensi pedagogik yang berkembang dan diambang. Dengan demikian, ada beberapa hal yang masih harus diperhatikan dan dikembangkan.

Hasil penelitian menunjukkan sub-kompetensi pedagogik, yaitu gambaran bahwa guru BK dalam menguasai teori dan praksis pendidikan mencapai rata-rata $61 \%$ dengan kategori kompeten. Kategori kompeten berarti kinerja guru BK dalam menguasai ilmu pendidikan dan landasan keilmuannya, mengimplementasikan prinsip-prinsip pendidikan dan proses pembelajaran, serta menguasai landasan budaya dalam praksis 
pendidikan sudah dikuasai dengan baik dalam mengimplementasikan layanan bimbingan dan konseling di sekolah sesuai dengan Permendiknas no. 27 tahun 2008.

Selain itu, gambaran bahwa guru BK dalam mengaplikasikan perkembangan fisiologis dan psikologis serta perilaku konseli mencapai rata-rata 29\% dengan kategori diambang. Kategori diambang berarti kinerja guru BK dalam mengaplikasikan kaidahkaidah perilaku manusia, perkembangan fisik dan psikologis individu, kepribadian, individualitas dan perbedaan konseli, belajar, keberbakatan, serta kesehatan mental terhadap sasaran pelayanan bimbingan dan konseling dalam upaya pendidikan cukup dikuasai dalam mengimplementasikan layanan bimbingan dan konseling di sekolah sesuai dengan Permendiknas no. 27 tahun 2008.

Terakhir, gambaran bahwa guru BK dalam menguasai esensi pelayanan bimbingan dan konseling dalam jalur, jenis, dan jenjang satuan pendidikan mencapai rata-rata $24 \%$ dengan kategori berkembang. Kategori berkembang berarti guru BK perlu meningkatkan kinerjanya dalam menguasai esensi bimbingan dan konseling pada satuan jalur pendidikan formal, nonformal maupun informal, pada satuan jenis pendidikan umum, kejuruan, keagamaan, dan khusus, serta satuan jenjang pendidikan usia dini, dasar dan menengah, serta tinggi karena aspek ini berada paling rendah di antara lainnya dan dinyatakan belum sesuai dengan standar kompetensi pada Permendiknas no. 27 tahun 2008.

Penguasaan kompetensi pedagogik yang baik mencerminkan bahwa seorang konselor dapat menguasai dan mengimplementasikan asas dan prinsip bimbingan dan konseling dalam menjalankan layanan bimbingan dan konseling kompherensif. Dalam penelitian ini, secara umum kompetensi pedagogik guru bimbingan dan konseling di SMA Negeri se-Kota Bandung sudah mencapai kategori kompeten, namun tetap memerlukan peningkatan dan pengembangan di beberapa indikator untuk mencapai kinerja yang profesional.

Tabel 3. Distribusi Frekuensi Gambaran Kompetensi Profesional Guru Bimbingan dan Konseling di SMA Negeri se-Kota Bandung

\begin{tabular}{llllll}
\hline $\begin{array}{l}\text { Kompetensi } \\
\text { Profesional }\end{array}$ & $\begin{array}{l}\text { Sangat } \\
\text { Kompeten }\end{array}$ & Kompeten & Diambang & Berkembang & Total \\
\hline Jumlah & 4 & 43 & 52 & 28 & 127 \\
\hline Persentase & $3 \%$ & $34 \%$ & $41 \%$ & $22 \%$ & $100 \%$ \\
\hline
\end{tabular}

Pemaparan hasil analisis deskriptif persentase data penelitian pada kompetensi profesional guru bimbingan dan konseling di SMA Negeri Se-Kota Bandung menunjukkan bahwa 3\% guru BK berada pada kategori sangat kompeten, 34\% guru BK berada pada kategori kompeten, $41 \%$ guru BK berada pada kategori diambang, dan sisanya $22 \%$ guru BK berada pada kriteria berkembang. Hasil penelitian untuk kompetensi profesional, didapatkan bahwa sebagian besar guru BK masih belum dapat mencerminkan diri sebagai konselor profesional.

Dari hasil penelitian, diperoleh gambaran bahwa kompetensi profesional guru BK yang berada pada kategori diambang yaitu aspek merancang program bimbingan dan konseling dengan rata-rata sebesar 50\%, selain itu aspek memiliki kesadaran dan komitmen terhadap etika profesional serta menguasai konsep dan praksis penelitian 
dalam bimbingan dan konseling memiliki rata-rata yang sama yaitu sebesar $43 \%$, dan aspek menilai proses dan hasil kegiatan bimbingan dan konseling memiliki rata-rata sebesar 28\%. Kategori diambang berarti kompetensi guru BK dalam aspek tersebut sudah cukup dikuasai dalam pelaksanaan layanan bimbingan dan konseling namun masih diperlukan beberapa peningkatan dan perbaikan untuk mencapai konselor yang profesional sesuai dengan standar pada Permendiknas no. 27 tahun 2008.

Gambaran kompetensi profesional guru BK yang berada pada kategori berkembang yaitu pada aspek menguasai konsep dan praksis asesmen untuk memahami kondisi, kebutuhan, dan masalah konseli memiliki rata-rata yang sama dengan mengimplementasikan program bimbingan dan konseling yang komprehensif sebesar $24 \%$, dan menguasai kerangka teoretik dan praksis bimbingan dan konseling dengan ratarata sebesar $20 \%$. Kategori berkembang berarti kompetensi guru BK dalam aspek tersebut masih sangat rendah dibandingkan yang lainnya dikarenakan guru BK belum terlalu menguasai aspek-aspek tersebut di dalam pelaksanaan layanan bimbingan dan konseling dan dinyatakan belum sesuai dengan standar kompetensi pada Permendiknas no. 27 tahun 2008.

Pada sub-kompetensi menguasai kerangka teoretik dan praksis bimbingan dan konseling memiliki persentase yang paling rendah dibandingkan yang lainnya dengan rata-rata sebesar $20 \%$. Dalam sub-kompetensi ini, ada lima hal yang perlu diaplikasikan oleh guru bimbingan dan konseling dalam mencapai layanan bimbingan dan konseling hal tersebut terkait penerapan hakikat pelayanan bimbingan dan konseling, arah profesi bimbingan dan konseling, dasar-dasar pelayanan bimbingan dan konseling sesuai kondisi dan tuntutan wilayah kerja. Pendekatan pelayanan dan kegiatan pendukung bimbingan dan konseling, dan format pelayanan bimbingan dan konseling. Kebanyakan guru bimbingan dan konseling masih kesulitan dalam menyeimbangkan antara teori dan praksis dalam pelaksanaan layanan. Sehingga apabila hal tersebut dibiarkan, guru bimbingan dan konseling akan kehilangan arah sebagai tenaga kerja profesional.

Pada sub-kompetensi menguasai konsep dan praksis asesmen untuk memahami kondisi, kebutuhan, dan masalah konseli memiliki rata-rata yang sama dengan mengimplementasikan program bimbingan dan konseling yang komprehensif sebesar $24 \%$. Dalam hal ini, guru bimbingan dan konseling perlu lebih banyak lagi menguasai mengenai penggunaan instrumen sesuai dengan kebutuhan peserta didik saat ini, menentukan teknik asesmen tes dan non tes dalam data yang ingin diungkap, menggunakan jenis instrumen/alat pengumpul databuntuk memperoleh informasi tentang peserta didik. Hal tersebut sangatlah penting dalam bidang bimbingan dan konseling sebagai alat pengungkap need assesmen siswa dalam mengembangkan program bimbingan dan konseling. Program bimbingan dan konseling yang disusun oleh guru BK haruslah berdasarkan fakta dan kesesuaian antara kebutuhan dan karakteristik konselinya. Dalam hal ini, terungkap bahwa kebanyakan guru BK masih kesulitan dalam menganalisis kebutuhan konseli, mengembangkan program bimbingan dan konseling, serta mengimplementasikan layanan bimbingan dan konseling kompherensif.

Pada sub-kompetensi menilai proses dan hasil kegiatan bimbingan dan konseling memiliki rata-rata sebesar $28 \%$. Dalam hal ini, guru bimbingan dan konseling seringkali tidak melakukan evaluasi dalam pembuatan program maupun pelaksanaan layanan ataupun menggunakan hasil evaluasi tersebut sebagai upaya untuk perbaikan. Padahal mengingat evaluasi itu penting sebagai bahan intropeksi kelebihan dan kekurangan atas 
pelaksanaan layanan bimbingan dan konseling seyogyanya guru bimbingan dan konseling dapat melakukan pengembangan program bimbingan dan konseling yang lebih baik.

Pada sub-kompetensi memiliki kesadaran dan komitmen terhadap etika profesional, menguasai konsep dan praksis penelitian dalam bimbingan dan konseling memiliki ratarata yang sama yaitu sebesar $43 \%$, dan aspek merancang program bimbingan dan konseling dengan rata-rata sebesar $50 \%$. Dalam hal ini, guru BK sudah memiliki komitmen serta menguasai kode etik profesional sebagai guru bimbingan dan konseling dengan tujuan untuk membantu mengembangkan potensi konseli secara optimal, mampu memahami pengembangan metode penelitian, melakukan penelitian dan memanfaatkan hasil penelitian tersebut sebagai bahan dasar dan bahan ajar dalam merancang program bimbingan dan konseling namun masih kesulitan dalam mengimplementasikannya.

Dalam Peraturan Menteri Pendidikan Nasional No. 27 Tahun 2008 tentang Standar Kualifikasi Akademik dan Kompetensi Konselor telah jelas disebutkan bahwa untuk menjadi guru BK atau konselor profesional harus dapat memenuhi standar kualifikasi dan kompetensi pedagogik, pribadi, dan sosial. Bedasarkan hasil penelitian yang mencapai rata-rata $43,5 \%$ guru bimbingan dan konseling di SMA Negeri se-Kota Bandung sudah hampir memenuhi standar kompetensi profesi guru bimbingan dan konseling.

\section{SIMPULAN}

Berdasarkan hasil analisis data penelitian yang diperoleh membuktikan bahwa hanya sebagian guru BK yang ada di SMA Negeri se-Kota Bandung berada pada kategori kompeten yang berarti telah mampu menguasai dan mengimplementasikan kompetensi guru BK khususnya kompetensi pedagogik dan profesional sesuai dengan Peraturan Menteri Pendidikan Nasional no. 27 tahun 2008 tentang Standar Kualifikasi dan Kompetensi Konselor. Maka, guru BK di SMA Negeri Se-Kota Bandung telah paham dan kompeten dalam melaksanakan pelayanan bimbingan dan konseling secara profesional walaupun masih memerlukan beberapa peningkatan dan pengembangan di beberapa aspek yang masih kurang dikuasai dikarenakan sebagian besar sub-kompetensi menunjukkan kategori diambang. Bagi peneliti selanjutnya yang memiliki ketertarikan terhadap kompetensi guru bimbingan dan konseling dapat membuat dan menguji keefektifan program pelatihan yang sesuai untuk meningkatkan kompetensi guru bimbingan dan konseling.

\section{REFERENSI}

Anisah, L. (2016). Kompetensi profesional konselor dalam penyelenggaraan penelitian tindakan bimbingan dan konseling. Jurnal Konseling GUSJIGANG, 2(1), 59-64.

Fuad, M. (2009). Kualitas pribadi konselor: Urgensi dan pengembangannya. KOMUNIKA: Jurnal Dakwah dan Komunikasi, 3(2), 247-254.

Kamaluddin, H. (2011). Bimbingan dan konseling sekolah. Jurnal Pendidikan dan Kebudayaan, 17(4), 447-454 
Mudjijanti, F. (2014). Pengaruh kualitas pribadi konselor terhadap efektivitas layanan konseling di sekolah. Widya Warta, 2(2), 260-280.

Nurrahmi, H. (2015). Kompetensi profesional guru bimbingan dan konseling. AlHikmah, 9(1), 44-60.

Permendiknas No. 27 Tahun 2008 tentang Standar Kualifikasi Akademik dan Kompetensi Konselor.

Retnowati, T. (2016). Meningkatkan kompetensi guru bk melaksanakan layanan bimbingan klasikal melalui supervisi akademik. Jurnal Penelitian Tindakan Bimbingan \& Konseling, 2(2), 1-8.

Rafiqah, T. (2016). Kompetensi guru bimbingan dan konseling dan upaya pembinaan. Jurnal Dimensi, 2(1), 1-11.

Sedarmayanti. (2017). Perencanaan dan pengembangan SDM untuk meningkatkan kompetensi, kinerja, dan produktivitas kerja. Bandung: Refika Aditama.

Suherman, U. (2015). Manajemen bimbingan dan konseling. Bandung: Rizki Press.

Undang-Undang Republik Indonesia No. 14 Tahun 2005 tentang Guru dan Dosen. 